\title{
Academic Supervision of Madrasah's Headmaster in Efforts to Improve Teachers 'Professionalism in MAN 1 Musi Banyuasin
}

\author{
Mutmainah $^{1 *}$, Happy Fitria ${ }^{2}$, Achmad Wahidy ${ }^{2}$ \\ ${ }^{1}$ MAN 1 Musi Banyuasin \\ ${ }^{2}$ Universitas PGRI Palembang \\ *Corresponding author. E-mail:mutmainahm4884469@gmail.com
}

\begin{abstract}
This study aims to identify and describe the aspects that are supervised by the head of Madrasah in an effort to help improve teacher professionalism, approaches to academic supervision, academic supervision techniques, describe the steps of academic supervision, describe the problems faced in supervision. academics by the principal in an effort to help efforts to help improve teacher professionalism at MAN 1 Musi Banyuasin in teaching. This study uses a qualitative method. Data collection techniques are interviews, observation and documentation. Data were analyzed using interview analysis techniques, observation and documentation. The results show that it shows that the teachers are already good at teaching but must be even more active in using ICT in information and communication technology in learning to improve their professionalism as professional teachers. Either with professional improvement training or training held by the Ministry of Religion or the head of madrasah. Because a teacher who is said to be a professional is a teacher who meets standard requirements in terms of academics, competence, profession, and performance as a teacher.
\end{abstract}

Keywords: Academic Supervision, Principal of Madrasah, Teacher Professionalism

\section{INTRODUCTION}

Education is one of the most critical and strategic aspects of growth and change in all fields, including regional development, so decentralization of education in the sense of regional autonomy cannot be negotiated in order to enhance the quality of education and human capital [1]. The success of education is largely determined by the ability of the principal in managing all resources in the school. This is consistent with what Mulyasa stated, 2004 that the principal is one of the components of education that has the most role in improving the quality of education. From the above opinion that the principal is a person who plays an important role in determining the success and improvement of the quality of education through his performance in school management.

One of the programs that can be implemented to improve quality education is the implementation of assistance to teachers or better known as supervision. The principal as the education leader in the school has a duty in the field of supervision. The Directorate General of Quality Improvement of Teachers and Education Personnel of the Ministry of National Education explicitly stated that the duties in the field of supervision are the duties of the principal relating to training teachers for teaching improvement. Supervision is an effort to provide assistance to teachers to improve or improve the teaching and learning process and situation. The final goal and supervision activities is to improve student learning outcomes.

Based on this description, it can be seen that in an effort to improve and enhance the learning process carried out by the teacher, the principal is in charge of organizing and carrying out supervision activities.

The reality of teacher professionalism in the learning process at this time is still diverse. According to Sulipan [2] problems related to teacher conditions include the diversity of teacher abilities in the learning process and mastery of knowledge. The teacher has not been able to show a professional performance even though if forced the teacher can do his job according to the demands. Often times the teacher does not prepare and understand the preparation of lesson plans and so on. The improvement of teacher professionalism is supported by the skills and performanceof the teacher himself [3].

This is also in accordance with the opinion of Prasojo and Sudiyono [4] explains that teacher resources grow and develop which in their development requires academic supervision 
assistance and the role of the principal in conducting academic supervision. Academic supervision is not to assess teacher performance, but to help teachers develop their professionalism [5].

Furthermore, Prasojo and Sudiyono [4] state the target and academic supervision are teachers in the learning process, which consists of the main material in the learning process, preparation of syllabus and lesson plans, selection of learning strategies / methods / techniques, use of media and information technology in learning, assessing the learning process and learning outcomes. Human resources must be trained in information technology so that they can become experienced teachers [6]. From this opinion, it is clear that the main target of academic supervision is the teacher in carrying out the learning process which includes planning learning, carrying out learning activities, and assessing the learning process and results. Therefore, in his role as academic supervisor, the principal has a duty to develop and improve the ability of teachers to carry out the learning process at school. Kartini et al note that there is a major influence on the success of teachers between principal leadership, academic supervision and professional competence at the same time [7].

The principal as the leader of an institution in a school has a significant role in fostering the ability of teachers in the learning process. To make teachers become professionals does not only improve their competence, either through upgrading, training or getting opportunities to learn again, but also needs to pay attention to teachers and other aspects such as increasing discipline, providing motivation, providing guidance through supervision. Therefore, the principal as the school leader must always conduct monitoring and guidance to teachers in an effort to increase teacher professionalism. Teachers must carry out a more creative learning process for students in order to develop their professionalism [8].

With this supervision, it is hoped that it can help the learning process, especially helping teachers in teaching in class. Even though during the Covid-19 pandemic, teachers taught through applications such as Google Classroom, WA Group, and E Learning Madrasah which started from preparation, implementation, to learning evaluation. Supervision of teachers at Madrasah Aliyah Negeri 1 Musi Banyuasin and the follow-up has not been carried out, so the professional competence of teachers has not been going well. Teacher's competencies include pedagogic, personality, social, and professional competencies obtained through professional education [9].
In the learning process where in 2020 Indonesia even the whole world is affected by the Covid-19 outbreak which causes learning to be carried out from home. In this case, of course there are many problems faced by a number of communities, both students, parents and teachers. However, in this case the teacher teaches in a different way. Based on interviews with the Deputy Head of Madrasah for Curriculum Affairs and teachers, it was found that problems arose related to learning activities, besides that the methods and learning tools were temporarily different from the previous year, there were still many teachers who were confused about how to teach using various applications.

These problems include the absence of supervision this semester even though the Covid-19 period teachers must still be guided and nurtured in order to achieve good learning goals. As a result, many teachers deliver lessons that are not in accordance with the steps in the lesson plan, such as suggesting students to read the prayer first before starting learning, providing motivation, and many others.

There are still some teachers who teach at will, because teachers don't want to bother with online learning. This happens because the head of the Madrasah has not conducted academic supervision. This trend has an impact on teachers who do not receive guidance from the head of Madrasah in carrying out teaching and learning activities, especially during the Covid-19 pandemic.

\section{METHODS}

The research method that will be used to examine the problem is a qualitative descriptive method. This means that any findings in the field that are closely related to the questions addressed in the previous chapter are described in accordance with reality, not making it up and will then be analyzed using a qualitative approach [10]. Qualitative research is carried out to build knowledge through understanding and discovery (meaning and discovery), inductive and divertic reasoning is very dominant in the qualitative study process, qualitative research intends to give meaning to phenomena holistically and must playing himself actively in the whole process of study.

To achieve the objectives of qualitative research, researchers used qualitative data collection techniques, namely observation, interviews, and documentation.

\section{RESULTS AND DISCUSSION}

The results of the study were directed at efforts to reveal the results of research findings at MAN 1 
Musi Banyuasin which were guided by the focus of research problems regarding the Academic Supervision of madrasah principals in an effort to increase professionalism towards teachers at MAN 1 Musi Banyuasin. Descriptions relating to the specific findings of this study are compiled based on the results of observations, interviews and documentation during the study.

\section{1) Academic Supervision Program Planning at MAN 1 Musi Banyuasin}

Academic supervision activities, including planning, implementation and assessment of the learning process. Therefore the target of teacher academic supervision starts from planning, which includes preparing learning tools, implementation, namely how to carry out the learning process, which involves the use of learning strategies / methods / techniques, class management both online and offline. In preparing the academic supervision program the principal can also involve teachers, especially in determining the schedule of supervision and who will be supervised.

Thus, they participate in these activities and are also responsible for its implementation. Then on the other hand they can know and understand academic supervision that is carried out early on, so that they can prepare themselves to complete class administration and learning administration. With the existence of togetherness in preparing the program, all parties will feel valued and will be able to eliminate misunderstandings between the principal of the madrasah and the teacher.

For this reason, it is necessary to formulate and socialize an academic supervision program as initial coaching for teachers, namely conveying and explaining the meaning, purpose and benefits of academic supervision.

In accordance with the Ministry of National Education [11] states that: "The scope of academic supervision planning includes a number of things that are interrelated with one another, namely related to 1) Implementation of the curriculum, 2) Preparation for implementation and assessment of learning by teachers, 3) achievement. graduate competency standards, process standards, content standards, and implementing regulations. 4) improving the quality of learning through development ". Academic supervision activities carried out by the head of the madrasah MAN 1 Musi Banyuasin stated that the head of the madrasah carried out planning in the form of compiling an academic supervision program with the deputy head of the madrasah as a vice curriculum.
Then the next step is to determine the goals, objectives to be achieved and create a team of assistant principals in implementing academic supervision. After that, the head of the madrasa held a meeting or outreach to other teachers on each new teaching about the importance of implementing academic supervision even though it was still in a state of the Covid-19 pandemic.

With the socialization of these teachers it was also agreed that the implementation schedule was in accordance with what was agreed. The head of the madrasah also conveyed the purpose of holding academic supervision and what areas would be supervised. Before conducting supervision, a school principal must make plans such as learning tools (syllabus and lesson plans), supervision schedules, supervision instruments, supervision techniques, analysis of supervision results, results of supervision and follow-up on supervision results, etc. Making syllabus and lesson plans and designing assessments have become routine teacher activities, but making supervision instruments starts from the assessment instruments for the preparation of teacher tools (syllabus and lesson plans).

This planning will then be carried out into supervisory activities based on a predetermined schedule. the implementation of academic supervision is assessed by the supervisor based on the assessment instrument that has been prepared. From this assessment, it will continue to be monitored, assessed and followed up so that teacher professionalism will increase. From the above statement the implementation of academic supervision of the principal of the MAN 1 Musi Banyuasin madrasah in making program planning was carried out by meeting with teachers.

By making plans with curriculum representatives, it will be further disseminated to all teachers in routine meetings, even though the meetings are with the Zoom meeting application and occasionally use face to face by complying with health protocols so that a schedule for implementing academic supervision is determined.

\section{2) Preparation for Academic Supervision of the head of madrasah in MAN 1 Musi Banyuasin}

After planning, the head of madrasah prepares supervision schedules, supervision instruments, supervision techniques which are different from usual because the supervision techniques will be carried out online, analysis of supervision results, results of supervision and follow-up on supervision results.

Apart from the principal, the teacher also has preparations, including:

(1) Syllabus.

(2) Learning Implementation Plan (RPP). 
(3) Annual Program.

(4) Semester Program.

(5) Implementation of the learning process.

(6) Assessment of learning outcomes.

(7) Supervision of the learning process etc.

Based on the data above, the researcher also adds the conclusion that both madrasah principals and teachers must also prepare learning quotas because they do not run out of quotas while being supervised or vice versa. Because of good planning, until implementation is slightly different from the previous year due to the Covid-19 pandemic where learning activities are carried out from home and rely on ICT, information and communication technology.

\section{3) Implementation of Academic Supervision for Madrasah principals in MAN 1 Musi Banyuasin}

Based on the analysis of research data related to academic supervision carried out by the principal of madrasah in an effort to improve professionalism towards teachers at MAN 1 Musi Banyuasin, the implementation is slightly different because in this implementation the supervision is carried out using online media such as the WA Group, Google Classroom and Elearning madrasah.

In carrying out academic supervision, the principal can take advantage of information technology such as computers / laptops to compile instruments. In addition, in making observations the principal of the madrasa can use digital media such as a voice recorder and / or camera or can be screened. The purpose of using information technology is so that the implementation of academic supervision can run more effectively and a quality learning process, especially during the pandemic period which requires all learning activities to be carried out at home by relying on a network. In the implementation of learning planning supervision, there are 3 things that need to be the initial basis for the principal to carry out academic supervision.

1) Review the learning administration tools Documents needed by the teacher in carrying out the learning process (annual program, semesterm syllabus program, lesson plans, educational calendar, lesson schedule, list of grades, etc.). So the principal of the madrasah sees and checks the equipment that was previously planned in the socialization, whether it has been prepared by the teacher in question during the implementation of academic supervision.

2) Studying the Learning Implementation Plan (RPP) In studying the lesson plans based on the following guidelines: a. Definition of Learning Implementation Plan (RPP). b. The principle of preparing a Learning Implementation Plan (RPP), which for this year the RPP is in the form of an emergency Covid-19 RPP which is only 1 sheet c. Develop supervision instruments. The academic supervision instrument is a tool used by madrasah principals to identify the profile of teachers' abilities in planning and implementing learning and learning assessments. The principal of madrasah can use existing instruments, both instruments that have been used in previous school supervision and in the form of standard instruments of relevant literature.

Whereas the implementation of academic supervision, the teacher first chooses to teach using what method, if the teacher uses the teaching method using the Elerning Madrasah application, the learning media in the RPP must use Madrasah Elerning. If what is written in the lesson plan is different, of course there will be all the assessments prepared by the head of the madrasah.

Through academic supervision activities, madrasah principals ensure that teachers carry out their teaching duties properly and students receive the best learning services. Through academic supervision, teachers are expected to improve the quality of the learning process, and madrasah principals can also create teacher professional development programs. This can be achieved if the teacher gets help from the principal of madrasa in developing his ability to manage the learning process in order to achieve learning objectives.

Distance learning uses various methods, such as using online, namely Elearning Madrasah, Google Classroom, Zoom, WhatsApp Group (WAG), and others.

The emergency response period for the Covid 19 pandemic is not clear for how long. Like it or not, the principal has to change the strategy of supervision carried out by his teacher, especially related to academic supervision. This needs to be done because teacher learning is no longer done face-to-face in the classroom, but online (online), offline (outside the network) or a combination of the two (blended).

At the MAN 1 Musi Banyuasin school, distance learning uses various methods, such as: utilizing the Elearning madsarah WhatsApp group (WAG), google classrooms, combining television shows with project assignments, or sending short messages so students read books they like.

All tasks and distance learning models are designed to remain meaningful, interesting, but also not burdensome for students while studying at home during the pandemic, as mandated by the 
Circular of the Minister of Education and Culture, the Regent and the Head of the Education Office and the Ministry of Religion. Changes in learning as described above need to be balanced and followed by changes in the supervision model carried out by the principal. The model applied must be adaptive to changes that occur in learning such as patterns and approaches, strategies and methods, tools or tools used, management of the learning environment, and assessments made. The main thing that has changed in terms of academic supervision of distance learning is that supervision is carried out remotely.

In essence, this supervision is carried out to ensure that the distance learning carried out by the teacher can be carried out properly and in accordance with the achievement targets that have been formulated.

\section{3) Evaluation of Academic Supervision at MAN 1 Musi Banyuasin}

This research shows that the evaluation of academic supervision at MAN 1 Musi Bnyuasin by the head of the madrasah has been carried out in accordance with existing procedures. This evaluation aims to determine whether the teacher has carried out the learning process well. The evaluation carried out by the principal of madrasah is in order to improve teacher professionalism through learning by monitoring Academic Supervision activities, so that in the future we can increase our potential so that the objectives of the learning are conveyed to students effectively and efficiently.

According to Bloom, evaluation is a systematic collection of facts to determine whether in reality there has been a change in students and to determine the extent of change in the student's personality or not. This means that evaluation is a very important thing to do, because the evaluation of the supervision activities carried out by the head of madrasah has a positive impact. With supervision to help teachers develop their professional character, seen from the changes in the way teachers teach. Because one of the references for this professional attitude is pedagogical competence. Certification is a requirement to become a professional teacher, there are 16 teachers who have been certified and are able to behave professionally, but there are also teachers who are not yet able to be professional.

Therefore this evaluation can motivate the teachers and be used as an input for the teacher for their actions which should be maintained and which should be eliminated. In addition, it is also evaluated from the supervision activities carried out which greatly affect not only teachers, but also institutions, because if the institution has professional teachers, the educational institution will have good quality.

Based on the results of observations, interviews and documentation studies, it shows that teachers are already good at teaching but must be even more active in using ICT in information and communication technology in learning to improve their professionalism as professional teachers. Either with professional improvement training or training held by the Ministry of Religion or the head of madrasah. Because a teacher who is said to be a professional is a teacher who meets standard requirements in terms of academics, competence, profession, and performance as a teacher.

\section{CONCLUSION}

The role of the head of madrasah as a supervisor in improving professionalism towards teachers at MAN 1 Musi Banyuasin is by making the following efforts: a). Conducting discussions with the deputy head of madrasah in the field of curriculum, b) Doing planning related to the holding of academic supervision at Man 1 Musi Banyuasin, c) Holding regular discussions / deliberations and meetings for evaluation both virtual and face-to-face in compliance with health protocols, d Provide activities to increase teacher professionalism. For example: education and training, seminars, MGMP, whokshop, training The process of implementing supervision that is used by the head of madrasah in increasing professionalism for teachers at MAN 1 Musi Banyuasin is by viewing and correcting reports on LPJJ distance learning results that have been made by teachers every time after teaching through WA Group, and you can also see learning activities on the Madrasah Elearning Application.

Supporting factors for the supervision of madrasah principals are: signal constraints, miss communication, and there are still some teachers who cannot use the Elerning madrasah application so that they teach using other media such as Google Classroom and Wa Group.

\section{ACKNOWLEDGMENT}

Gratitude is given to the teachers of MAN 1 Musi Banyuasin, Chancellor of the PGRI Palembang University, Director of Postgraduate Program at PGRI Palembang University and Head of the Education Management Masters Study Program of the PGRI Palembang University who have helped in completing this journal which is a product of the thesis. Then thank you also to the friends of the PGRI Palembang University Postgraduate students and all those who have helped write and publish this journal. 


\section{REFERENCESS}

[1] Rohma, S., Harapan, E., \& Wardiah, D. (2020). The Influence of School-Based Management and Teacher's Professionalism toward Teacher's Performance. Journal of Social Work and Science Education, 1(1), 1323. Retrieved from https://ejournal.karinosseff.org/index.php/jsws e/article/view/6

[2] Sulipan. (2008). Standar Kompetensi Guru [Teacher Competency Standards] http://www.geocities.com/pengembangan_sek olahlstandarguru.html (Diakses 10 November 2020)

[3] Ruslan, Lian, B., \& Fitria, H. (2020). The Influence of Principal's Situational Leadership and Teacher's Professionalism on Teacher's Performance. International Journal of Progressive Sciences and Technologies (IJPSAT), 20(1). Retrieved from https://ijpsat.ijshtjournals.org/index.php/ijpsat/article/view/1733

[4] Prasojo, L. D., \& Sudiyono. (2011). Supervisi Pendidikan [Education Supervision]. (Yogyakarta: Gava Media.

[5] Khasanah, U., Kristiawan, M., \& Tobari. (2019). The Implementation of Principals' Academic Supervision in Improving Teachers' Professionalism in the State Primary Schools. International Journal of Scientific \& Technology Research, 8(8).

[6] Rahmadoni, J. (2018). Perancangan Simulasi Pembelajaran Kriptografi Klasik Menggunakan Metode Web Based Learning [Designing Classical Cryptography Learning Simulation Using Web Based Learning Method]. INTECOMS: Journal of Information Technology and Computer Science, 1(1), 3443.

https://doi.org/https://doi.org/10.31539/inteco $\underline{\text { ms.v1i1.160 }}$

[7] Kartini, D., Kristiawan, M., \& Fitria, H. (2020). The Influence of Principal's Leadership, Academic Supervision, and Professional Competence toward Teachers' Performance. Education and Training for Strengthening Principal to Effective Schools. International Journal of Progressive Sciences and Technologies (IJPSAT), 20(1).

[8] Kristiawan, M., \& Rahmat, N. (2018). Peningkatan Profesionalisme Guru Melalui Inovasi Pembelajaran [Improving Teacher Professionalism through Learning Innovations]. Jurnal Iqra': Kajian Ilmu Pendidikan, 3(2), 373 - 390. https://doi.org/10.25217/ji.v3i2.348

[9] Turmini., Kristiawan, M., \& Sari, A. P. (2020). The Influence of Education, Training, and Experience towards Teacher's
Professionalism. Electronic Research Journal of Social Sciences and Humanities Vol 2: Issue II. ISSN: 2706 - 8242.

[10] Danim, S. (2002). Menjadi Peneliti Kualitatif [Become a Qualitative Researcher]. Bandung: Pustaka Setia.

[11] Ministry of National Education. (2014). Supervisi Akademik dalam Peningkatan, Profesionalisme Guru [Academic Supervision in Improvement, Teacher Professionalism]. Jakarta: Departemen Pendidikan Nasional Direktorat Jenderai Peningkatan Mutu Pendidik dan Tenaga Kependidikan. 